\title{
MENINGKATKAN HASIL BELAJAR SEJARAH DENGAN MENERAPKAN MODEL PEMBELAJARAN KOOPERATIF TIPE PERMAINAN KARTU DOMINO PADA SISWA KELAS XI IPS4 SMA NEGERI I KABAWO
}

\section{IMPROVING HISTORY LEARNING OUTCOMES BY APPLYING COOPERATIVE LEARNING MODEL TYPE OF GAME DOMINO CARDS IN CLASS XI IPS4 STUDENTS OF NEGERI I KABAWO}

\author{
Fajarudin Munando \\ email:_ajarudin_munando89@gmail.com
}

\author{
Anwar \\ Email:anwar@uho.ac.id
}

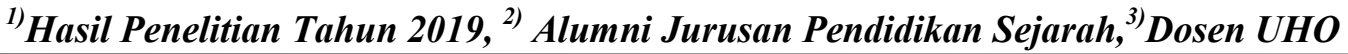

\begin{abstract}
ABSTRAK: Fokus penelitian ini adalah: 1) Untuk meningkatkan aktivitas belajar siswa pada mata pelajaram sejarah di kelas XI IPS 4 SMA Negri I Kabawo Kabupaten Muna. 2)Untuk meningkatkan keefektivitas mengajar guru pada mata pelajaran sejarah pada siswa kelas XI IPS ${ }_{4}$ SMA Negri I Kabawo Kabupaten Muna. 3) Untuk meningkatkan hasil belajara siswa pada mata pelajaran sejarah pada siswa kelas XI IPS 4 SMA Negri I Kabawo Kabupaten Muna. Penelitian ini termasuk penelitian tidakan kelas (PTK) yang dilakukan dengan prosedur pelaksanaannya beberapa tahap, yaitu: perencanaan, pelaksanaan tindakan, pengamatan, serta refleksi. Teknik pengumpulan data yang digunakan dalam penelitian ini adalah dengan memberikan tes tertulis dalam bentuk uraian pada tiap akhir siklus pembelajaran. Sesudah itu juga dengan dilakukan pengamatan terhadap efektivitas mengajar guru dan aktivitas belajar siswa. Teknik analisis data yang digunakan adalah analisis statistic sederhanan yaitu analisis deksripsi untuk mencari rata-rata persentase. Teknik analisis ini digunakan untuk mengetahui peningkatan hasil belajar siswa sesudah melakukan kegiatan pembelajaran dengan meenerapan model pembelajaran kooperatif tipe permainan kartu domino. Hasil penelitian ini menujukan bahwa: 1) persentase pelaksanaan efektifitas mengajar guru berdasarkan skenario penelitian yang dilaksanakan mengalami peningkatan setiap siklusnya. Persentase yang diperoleh pada siklus I sebesar $72,73 \%$ pada siklus II meningkatan mencapai $90,01 \%$. 2) Aktivitas belajar siswa dengan menerapan model pembelajaran koopereatif tipe permainan kartu domino sudah menujukan peningkatan efektif. Perensentase yang diperoleh yaitu pada siklus I sebesr 25\% dan pada siklus II mencapai persentase 90\%. 3) Hasil belajar siswa meningkat dengan model pembelajaran kooperatif tipe permainan kartu domino dengan pesentase ketuntasan $89 \%$. Dengan hasil tes siklus I yaitu sebesar $55,22 \%$ dengan nilai rat-rata 73 . Pada siklus II mengalami peningkatan menjadi $86,96 \%$ dengan nilai rata-rata 82 dengan demikian penelitian tindakan kelas ini telah berhasil.
\end{abstract}

\section{Kata Kunci: Kooperatif, Model, Permainan Kartu Domino,}

ABSTRACT: The focus of this study are: 1) To improve student learning activities in the history of history in class XI IPS4 SMA Negeri 1 Kabawo, Muna Regency. 2) To improve the effectiveness of teaching teachers on history subjects in class XI IPS4 students of SMA Negri I Kabawo, Muna Regency. 3) To improve student learning outcomes in history subjects in class XI IPS4 students at SMA Negri I Kabawo, Muna Regency. This research includes classroom action research (CAR) which is carried out with several stages of implementation procedures, namely: planning, implementing actions, observing, and reflecting. The data collection technique used in this study is to provide a written test in the form of a description at the end of each learning cycle. After that also the observation of the effectiveness of teacher teaching and student learning activities was carried out. The data analysis technique used is a simple statistical analysis that is descriptive analysis to find the average percentage. This analysis technique is used to find out the increase in 
student learning outcomes after conducting learning activities by applying cooperative learning models to the type of domino card game. The results of this study show that: 1) the percentage of the implementation of the effectiveness of teaching teachers based on research scenarios carried out has increased each cycle. The percentage obtained in the first cycle of $72.73 \%$ in the second cycle increased to reach $90.01 \%$. 2) Student learning activities by applying the cooperative learning model of the type of domino card game have been aimed at effective improvement. The percentage obtained is $25 \%$ in the first cycle and $90 \%$ in the second cycle. 3) Student learning outcomes increase with the type of domino card cooperative learning model with a percentage of completeness $89 \%$. With the results of the first cycle test that is equal to $55.22 \%$ with an average value of 73 . In the second cycle increased to $86.96 \%$ with an average value of 82 thus this class action research has been successful.

\section{Keywords: Cooperative, Model, Domino Card Game}

\section{PENDAHULUAN}

Salah satu tujuan pendidikan adalah mempersiapkan siswa dalam hal pengetahuan dan keterampilan yang dibutuhkannya, agar kelak dapat berfungsi sebagai orang dewasa. Dengan perubahan yang cepat, maka perlu dilakalukan peneliaian kembali tentang apa yang dibutuhkan dan dipelajari oleh siswa untuk mengimbangi tantangan dimasa depan. Sekolah sebagai penata sosial harus kondusif dan peka terhadap kebutuhan siswa dimasa mendatang untuk dapat mengembangkan pengetahuan dan menumbuhkan keterampilan pribadi siswa. Sebagaimana yang tercantum dalam Undang-Undang Nomor 20 Tahun 2003 Pasal 1, Ayat 1 Tentang Sisdiknas yang mengemukakan tentang tujuan pendidikan adalah usaha sadar dan terencana untuk mewujudkan suasana belajar dan proses pembeljaran agar peserta didik secara aktif menumbuhkan potensi dirinya untuk memiliki kekuatan spiritual keagamaan, pengendalian diri, kepribadian, kecerdasan, akhlak mulia, serta keterampilan yang diperlukan dirinya, masyarakat, bangsa dan bernegara. Pendidikan mempunyai peranan yang sangat penting dalam menumbuhkan dan mengembangkan potensi-potensi setiap indivdu dalam memcapai tujuan yang diharapkan.

Fokus perhatian dalam pendidikan adalah peserta didiknya, baik itu ditaman kanak-kanak, sekolah dasar, pendidikan menengah, maupun perguruan tinggi dan pendididikan untuk dewasa lainya. Pendidikan adalah sebagai usaha rujukan dan mengembangakan pribadi manusia, baik menyangkut aspek ruhanian dan jasmaniah. Tidak heran bila suatu kematangan yang bertitik akhir pada obtimalisasi perkembagan jiwa manusia, baru dapat tercapai bilamana berlangsung melalui proses kearah tujuan akhir perkembangan kepribadian manusia.

Menurut Aunurahman (2012: 35) belajar adalah suatu usaha sadar yang dilakukan individu dalam perubahan tingkah laku baik melalui latihan dan pengalaman yang menyangkut aspek-aspek kognitif, efektif dan psikomotor untuk memperoleh tujuan tertentu. Menurut Sagala (2005:13) siswa adalah penentu terjadi atau tidaknya proses belajar. Berhasil atau gagalnya pencapainnya tujuan pendidikan tergantung pda proses belajar mengajar yang dialami siswa dan pedidikan baik ketika para siswa di sekolah maupun di lingkungan keluarga sendiri. Dalam Sardiman belajar adalah serangkaian kajian jiwa raga, psiko fisik menuju keperkembangan pribadi manusia seutuhnya yang berarti menyangkut cipta, rasa dan karsa, rana kognitif, efektif dan psikomotor. (Sardiman A,M. 2016: 21)

Didaalam buku Winaputra (2008: 40) pengertian pembelajaran adalah serangkaian kegiatan yang dirancang untuk memungkinkan terjadinya proses belajar pada siswa. Menurut UU Nomor 20 tentang Sindiknas, pembelajaran adalah proses interaksi pesrta didik dengan pendidik dan sumber belajar pada suatu lingkungan belajar. Cirri utama dari pembeljaran adalah inisiasi, fasilitasi, dan peningkatan proses belajar siswa. Sedangkan komponen-komponen dalam pembelajaran adalah tujuan, materi. Kegiatan,dan evaluasi pembelajaran.

Menurut Hamulton (2000: 11) konsep hasil belajar merupakan suatu proses interaksi yang bukan hanya dalam rangka mentransfer informasi atau pengetahuan, tetapi juga memasyarakatkan berlangsungnya interaksi nilai dan sikap. Salah satu tujuan dari proses belajar mengajar di sekolah 
adalah agar tercapainya hasil yang maksimal. Hasil belajar merupakan hasil belajar yang ditunjukan dalam penampilan yang tepat sebagai akibat dari proses belajar yang terjadi melalui program yang menyediakan fakta-fakta, bukti-bukti, keterngan dan sebagainya.

Pembelajaran kooperatif mencakup suatu kelompok kecil yang bekerja sebgai sebuah tim untuk menyelesaikan sebauah masalah, menyelesaikan sebuah tugas,atau mengerjakan sesuatu untuk mencapai tujuan bersama (Erman dkk, 2003: 260). Dalam format pembelajaran kooperatif, setelah guru menyampaiakan materi pelajaran, para siswa tergabung dalam kelompok-kelompok kecil untuk berdiskusi dan menyelesiakan soal latihan, kemudian menyerahkan hasil kerja kelompok kepada guru.Selanjutnya memimpin diskusi tentang pekerjaan kelompok tersebut yang memebutuhkan penjelasan dan klarifikasi.

Mengoptimalkan pembelajaran kooperatif, keanggotaannya sebaiknya heterogen, baik kemampuan atau karakteristik lainnya.Untuk menjamin heterogenitas keanggotaan kelompok, sebaiknya gurulah yang membagi kelompok. Jika para siswa yang mempunyai kemampuan yang berbeda dimasukan dalam satu kelompok, maka dapat memberikan keuntungan bagi siawa yang berkemampuan sedang da rendah, sedangkan siswa yang pandai akan dapat mentransfer ilmu yang dimiliki. Ukuran kelompok akan berpengaruh pada kemampuan produktivitas kelompoknya. Ukuran kelompok yang ideal untuk pemeblajaran kooperatif adalah 3-5 orang (Rostiah, 2001: 17)

Menurut Ibrahim (2002: 20) agar siswa dapat bekerjasama dengan baik didalam kelompok perlu diajarkan keterampilan-keterampilan kooperatif pada pesrta didik. Keterampilanketerampilan tersebut adalah: 1) berada dalam tugas, yaitu berada dala kerja kelompok, merumuskan tugas yang menjadi tanggung jawabnya dengan melatih keterampialan siswa akan menyelesaiakan tugas dalam waktu yang tepat dengan karakteristik yang lebih baik, 2) mengambil giliran dan berbagi tugas, yaitu siswa bersedia menerima tugas dan membantu menyelesaikan tugas sehingga kegiatan akan terselasikan pada waktunya, 3) mendorong partisipasi, yaitu motivasi teman sekelompok untuk memberikan kontribusi tugas kelompok, 4) menengarkan dan aktif, yaitu mempehatiakan informasi yang disampaikan teman sehinnga anggota kelompok yang menjadi pembicara akan merasa senang kerena apa yang mereka sumbangkan itu berharga, 5) bertanya, yaitu menyampaikan informasi atau penjelasan lebih lanjut dari teman sekelompok apabila teman sekelompok tidak tahu jawabannya, baru menanyakan pada guru, hal ini penting karena siswa yang pasif dapat didorong untuk aktif.

Kartu domino bukanlah suatu kartu yang digunakan ornag untuk berjudi , melainkan suatu medel pembelajaran yang bentuknya 'dibuat sperti kartu domino untuk menarik menarik minat siswa dalam pembelajaran IPS, selain itu kartu domino juga memungkinkan siswa untuk lebih aktif dan proses belajar mengajar menjadi menarik dan siswa dapat berpikir kritis dalam pemecahan maslah yang muncul (Ginnis, 2008: 115)

Fenomena yang terjadi pada siswa SMA Negeri 1 Kabawo Kelas XI IPS 4 menunjukkan rendahnya hasil belajar siswa, sesuai dengan hasil wawancara terhadap guru sejarah, diperoleh informasi bahwa nilai siswa kelas XI IPS 4 selama dua tahun berturut-turut pada tahun ajaran 2013/2014 dan 2015/2016 semester II. Hal ini dapat dilihat dari rata-rata ulangan harian siswa pada meteri tersebut sebesar 68 sehingga belum memenuhi standar dari sekolah yaitu sebesar 76 atau belum mencapai Kreteria Ketuntasan Minimal (KKM), dengan rincian 9 orang telah memenuhi standar ketuntasan belajar dan 14 orang lainnya masih beradah dibawah standar minimal yang telah ditetapkan. "Salah satu penyebab rendahnya hasil belajar siswa adalah kurangnya inovasi guru dalam proses pembelajaran. Cara mengajar guru selama ini masih menggunakan metode konvensional. Seperti metode ceramah, Tanya jawab, penugasan.

Pembelajaran sejarah di kelas XI. IPS 4 pada SMA Negeri 1 Kabawo dirasakan siswa sebagai pelajaran yang sangat membosankan sehingga siswa kurang aktif dalam pembelajaran. Siswa juga menganggap pelajaran sejarah hanyalah pelajaran ynag menceritakan kejadian-kejadian masa lalu yang tidak akan terjadi lagi, serta hafalan tahun dan nama-nama tokoh yang harus diingat siswa. 


\section{MOTODE PENELITIAN}

Penelitian ini telah dilakukan di SMAN I Kabawo Kabupaten Muna semester II. Penelitian tindakan kelas ini dilakukan dalam dua siklus, untuk mengetahui peningkatan hasil belajar siswa dalam mengikuti mata pelajaran Sejarah dengan menerapkan model pembelajaran Kartu Domino. Subyek penelitian ini adalah siswa kelas $\mathrm{XI} \mathrm{IPS}_{4}$ SMANegri I Kabawo Kabupaten Muma.Siswa kelas XI IPS 4 berjumlah 23 yang terdiri dari: Laki-laki 11 dan Perempuan 12, dengan faktor yang diteliti terdiri atas: faktor siswa, guru, dan hasil belajar. Dalam suatu penelitian ilmiah, model pengumpulan data sangat berpengaruh dalam menentukan keberhasilan suatu penelitian terutama memperoleh kebenaran. Oleh karena itu, peneliti menggunakan model observasi, dokumentasi dan tes. Pengumpulan data biasanya menghasilkan catatan tertulis yang sangat banyak (Moleong, 2006: 234-235). Model observasi dilakukan dengan mengadakan penelitian langsung pada objek yang akan diteliti. Dengan melakukan observasi ini memungkinkan peneliti untuk mampu memahami situasi-situasi yang rumit. Situasi yang rumit memungkinkan terjadi jika peneliti ingin memperhatikan tingkah laku sekaligus (Moleong, 2006: 175). Dalam penelitian tindakan Kelas ini (PTK), peneliti bertindak sebagai observer yang mengamati proses pembelajaran menggunakan model pembelajaranKartu Domino. Dokumentasi adalah pemberian atau bukti-bukti dan keterangan-keterangan (seperti kutipan dari surat kabar, gambar dan sebagainya). Dokumen sudah lama digunakan sebagai sumber data dan dimanfaatkan untuk menguji, menafsirkan dan bahkan untuk meramalkan (Moleong, 2006: 217). Dalam penelitian ini, model dokumentasi dilakukan dengan cara mencari data-data yang dapat membantu dalam penelitian. Data tersebutantara lain mengenai foto-foto siswa dan guru dalam proses pembelajaran di kelas. Tes adalah alat ukur yang digunakan dalam suatu penelitian untuk menentukan tingkat keberhasilan siswa.dalam proses belajar-mengajar atau untuk menentukan suatu program pendidikan (Nasution, 1993 : 167).

Di dalam penelitian tindakan kelas ini, tes diberikan kepada siswa dalam setiap akhir siklus untuk menentukan keberhasilan siswa kelas XI-IIS ${ }^{4}$ Negeri 1 Kabawo kabupaten Muna. Tes yang diberikan berbentuk soal pilihan ganda, yang masing-masing soal berjumlah 20 butir. Sedangkan alokasi waktu yang dibutuhkan dalam mengerjakan soal adalah 60 menit. Penelitian ini dirancang sebagai suatu penelitian tindakan kelas dengan menggunakan model pembelajaran Kartu Domino, dimana dalam penelitian ini melibatkan guru mata pelajaran Sejarah di kelas yang digunakan sebagai tempat penelitian, untuk bersama melaksanakan penelitian. Dalam penelitian tindakan kelas ini terdapat empat komponen penting yaitu perencanaan, tindakan, pengamatan, dan refleksi. Empat langkah yang saling berkaitan itu dalam pelaksanaan penelitian tindakan kelas sering disebut dengan istilah Sikluas. Proses dalam penelitian tindakan kelas ini dilaksanakan dengan dua siklus, yaitu siklus I dan siklus II. Tiap-tipa siklus terdiri dari empat tahap yaitu perencanaan, tindakan, pengamatan/observasi, dan refleksi. Tiap siklus dilaksanakan dengan pembelajaran yang ingin dicapai (Arikunto,2006:16).

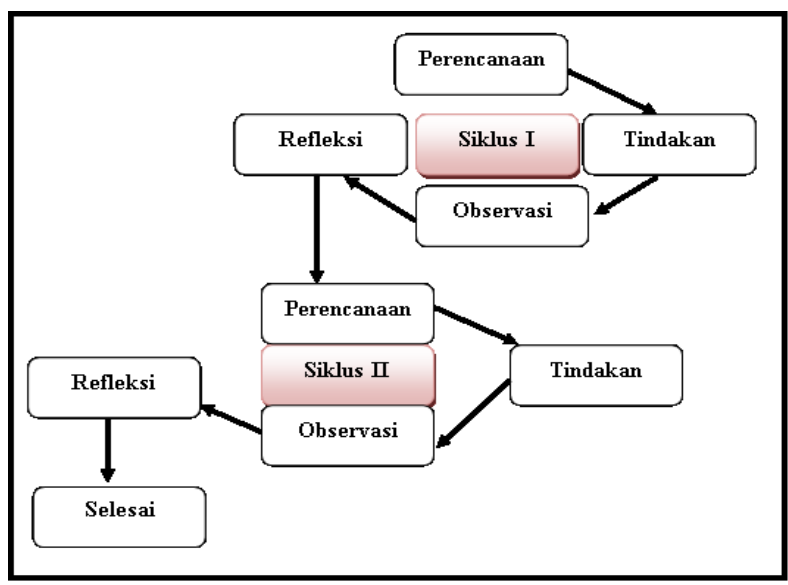

Gambar 2 : Siklus Penelitian 
Analisi tes hasil belajar siswa bertujuan untuk mengetahui tingkat ketuntasan belajar siswa yang diperoleh dari tiap siklus. Penguasaan materi pelajaran dapat dilihat dari nilai yang diperoleh siswa untuk setiap siklus. Untuk menetapkan nilai hasil belajar siswa dapat digunakan rumus sebagai berikut (Agung Purwoko, 2001: 103) $:$ Nilai $=\frac{\text { Skor yang diperoleh siswa }}{\text { Skor Maksimal }} \times 100 \%$

Siswa yang memperoleh nilai $<65 \%$ dinyatakan mengalami kesulitan dalam belajar dan siswa yang memperoleh nilai lebih dari atau sama dengan $65 \%$ dinyatakan telah tuntas belajar. Untuk mengukur ketuntasan belajar klasikal digunakan rumus (Agung Purwoko, 2001: 103): $\%=\frac{n}{N} \times 100 \%$

Keterangan :

$\begin{array}{ll}\% & \text { : Presentase Suatu Nilai } \\ \mathrm{n} & \text { : Jumlah Siswa Yang mendapat nilai }<6,5 \% \\ \mathrm{~N} & \text { : Jumlah Siswa. }\end{array}$

Ketuntasan klasikal dinyatakan berhasil jika persentase siswa yang tuntas belajar atau siswa yang mendapat nilai $=65 \%$ jumlahnya lebih besar atau samadengan $75 \%$ jumlah siswa didalam kelas.

Untuk pengukuran aktivitas dengan indicator motor activities dan diukur dengan menggunakan rubric sebagai berikut : (a) $5=$ baik sekali, (b) $4=$ cukup baik, (c) $3=$ baik (d) $2=$ kurang, (e) 1 = sangat kurang. Lembar aktivitas dianalisis menggunakan skor dengan menggunakan skala rentang 5 sampai 1 dengan 10 indikator motor aktivities. Skor maksimum 50 dan skor minimum 10. kemudian dianalisis menggunakan analisis persentase. Untuk analisis persentase digunakan rumus distribusi persentase yaitu (Arikunto, $2002: 246): P=\frac{S}{N} \times 100 \%$

Keterangan :

$\mathrm{P}$ : Persentase pelaksanaan setiap indikator.

$\mathrm{S}$ : Jumlah skor perolehan untuk setiap indikator.

$\mathrm{N}$ : Jumlah skor total.

Indikator yang digunakan untuk mengaturkeberhasilan penelitian ini terdiri atas 3, yaitu (1) Dari segi proses tindakan keefektifan mengajar guru dikatakan berhasil apabila minimal $90 \%$ skenario pembelaran berjalan dengan baik. (2) Dari segi proses aktivitas belajar siswa, tindakan dikatakan berhasil apabila minimal $90 \%$ siswa aktif. (3) Dari segi hasil belajar siswa, penelitian dikatakan berhasil apabila minimal $80 \%$ siswa telah mencapai kriteria ketuntasan minimal (KKM).

\section{HASIL PENELITIAN DAN PEMBAHASAN}

\section{Hasil Penelitian \\ Tindakan siklus I}

Berdasarkan hasil observasi keefektifan mengajar guru pada siklus I, terlihat bahwa keefektifan guru dalam melaksanakan pembelajaran dengan menerapkan model pembelajaran kooperatif tipe permainan kartu domino belum maksimal, dimana dari 11 aspek keefektifan guru yang diobservasi hanya 8 yang terlaksana dengan dengan persentase mencapai $72,73 \%$ artinya masih ada hal-hal yang masuk dalam kategori yang diobservasi namun masih kurang nampak pada aktiviutas guru selama proses mengajar berlngsung. Sehingga keefektifan mengajar guru pada siklus I belum mencapai indikator kibnerja yaitu $90 \%$

Adapun aktivitas guru yang kurang nampak atau penyebab sehingga belum tercapainya indikator kinerja terlihat pada kegiatan pendahuluan, guru belum memaksimalkan mengajukan pertanyaan untuk menggali informasi awal dari siswsa terkait dengan materi yang akan diajarkan, dalam hal ini guru telah mengajukan apresiasi/pertanyaan awal hanya saja kurang memberi kesempatan kepada siswa berpikir sejenak untuk menjawab atau menanggapi apresiasi/pertanyaan.Selamjutnya guru belum memberikan motivasi kepada siswa sehingga siswa masih kurang tertarik mengikuti pelajaran. Selanjutnya pada kegiatan inti guru belum membagi 
siswa kedalam kelompok secara heterogen, dan belum nampak memberikan apresiasi kepada siswa yang menjawab, selainitu juga pada kegiatan inti guru belum berkeliling dan belum meberikan arahan kepada siswa yang belum jelas/mengerti. Hal ini terjadi kerna guru belum terbiasa menggunakan model pembelajaran kooperatif tipe $\mathrm{p}$ [ermainan kartu domino. Selain irtu pada inti guru masih nampak mendominasi proses pelajaran dan siswa hanya pasif menerima materi. Pada kegiatan akhir, guru tidak terlihat memimbing siswa dalam menyimpulkan materi pelajaran berhubung jam pelajaran telah selesai.

Selain keefektifan mengajar guru, diamati pula aktivitas siswa selama proses pembelajaran berlangsung dengan tujuan untuk mengetahui bagaimana keaktifan siswa selama proses pembelajaran berlansung. Berdasarkan hasil observasi aktivitas siswa selama proses pembelajaran pada siklus I, terlihat bahwa aktivitas yang dilakukan siswa dalam proses pembelajaran dengan menerapkan model pembelajaran kooperatif tipe permainan kartu domino tergolong masih kurang dari 10 aspek yang diamati tidak ada satupun aktivitas yang kategori baik, dengan persentase capain siswa $25 \%$. Hal ini berarti bahwa keaktifan siswea dalam proses pembelajaran pada siklus I masih kurang. Analisis kegiatan siswa ini mengidentasikan bahwa kegiatan dalam proses pembeljaran pada siklus I belum dilakukan secara maksimal, sehinnga belum merangsang semangat siswa dalam mengikuti proses pembelajaran. Hal ini berarti bahwa pelaksanaan pembelajaran pada siklus I belum mengarah pada kegiatan siswa.

Adapun kelemahan/penyebab belum tercapainya indikator kinerja yaitu: (a) dalam memulai pelajaran siswa masih terlihat gadu sehinnga belum dapat menyimak penjelasan guru dengan baik, (b) siswa masih terlihat main-main menjawab/mengemukakan pendapat saat guru saat guru melakukan apersepsi, (c) siswa masih kurang/takut-takut dalam mengajukan pertanyan mengenai makna dari pembelajaran kartu domino, (d) sebagian besar siswa masih kurang aktif dalam diskusi kelompok, (e) siswa belum terlihat menyimpulkan pelajaran karena jam pelajaran telah selesai, sementara proses ini sangat penting untuk menguatkan kembali ingatan siswa tentang materi pelajaran yang telah selesai ddipelajari.

Setelah dilakukan proses pembelajaran selama 2 (dua) kali pertemuan, maka untuk mengetahui sejauh mana penguasan siswa terhadap materi yang diajarakn dan idikator keberhasilan siswa maka dilakukan evaluasi pada tangaal 11 Januari 2018. Dari hasil evaluasi diperoleh nilai hasil belajar siswa pada pembelajaran siklus I terlihat bahwa masih banyak siswa yang belum mencapai KKM, dimana KKM yang telah ditentukan oleh sekolah yaitu 76. Dari 23 siswa hanya 15 oarng yang mencapai KKM dengan persentase $65,22 \%$ dan 8 orang yang belum mencapai KKM dengan persentase $34,78 \%$. Hasil belajar juga dapat diketahui bahwa pada siklus I terlihat nilai ratarata hasil belajar siswa adalah 73 dengan nilai minimum 50 dan nilai maksimum 90. Adapun distribusi skor perolehan hasil belajar siswa disajikan pada tabel berikut:

Tabel 1 : Distribusi Frekuensi Skor Hasil Belajar Siswa Pada Siklus I

\begin{tabular}{cccc}
\hline No & Hasil Belajar & Jumlah & Persentase (\%) \\
\hline $\mathbf{1 .}$ & $0-50$ & 2 & 8,70 \\
$\mathbf{2 .}$ & $51-60$ & 4 & 17.39 \\
$\mathbf{3 .}$ & $60-71$ & 2 & 8,70 \\
$\mathbf{4 .}$ & $71-80$ & 11 & 47,83 \\
$\mathbf{5 .}$ & $81-90$ & 4 & 17.39 \\
& Jumlah & 23 & 100 \\
\hline
\end{tabular}

Sumber data: Diolah dari data penelitian

Dari tabel I di atas digambarkan bahwa: 2 orang siswa yang memperoleh nilai 0-50 dengan persemtase $8,70 \%, 4$ orang siswa yang memperoleh nilai 51-60 dengan persentase $17.39 \%, 2$ orang siswa yang memperoleh nilai 61-70 dengan persentase $8,70 \%, 11$ orang yang memperoleh nilai $71-$ 80 dengan persentase $47,83 \%$, dan 4 orang siswa yang memperoleh nilai $81-90$ dengan pertsentase $17.39 \%$,

Selanjutnya untuk melihat distribusi dan persentase ketuntasan hasil belajar siswa disajikan pada pada tabel berikut: 
Tabel 2: Analisis Ketntasan Hasil Belajar Siswa Pada Pembelajaran Siklus I

\begin{tabular}{ccc}
\hline Ketuntasan & Jumlah Siswa & Persentase (\%) \\
\hline Tuntas & 15 & 65,22 \\
Tidak tuntas & 8 & 34,78 \\
Jumlah & 23 & 100 \\
\hline
\end{tabular}

Sember data : diolah dari data penelitian

Dari tabel 2 diatas, terlihat bahwa jika dianalisis secara persentase maka ketuntasan belajar siswa mencapai $65,22 \%$, dengan demikian, indikator kinerja siswa secara klasikal belum mencapai target yang ditentukan dimana indikator kinerja yang ditentukan $80 \%$

Berdasarkan hasil observasi dan evaluasi kegiatan pembelajaran dengan menerapkan model pembelajaran kooperatif tipe permainan kartu domino pada siklus I belum maksimal, karena penerapan model pembelajaran kooperatif tipe permainan kartu domino ini merupakan baru pertama kali diterapkan dalam pembelajaran sejarah di SMA Negeri I Kabawo khususnya di kelas XI IPS4. Hal ini menyebabkan siswa masih kurang disiplin dalam pembelajaran karna belum terlalu memahami makna dari model pembelajaran kooperatif tipe permainan kartu domino, namun telah menujukan kemajuan/peningkatan persentase kelulusan siswa dibandingkan dengan pembelajaran sebelumnya yang tidak menggunakan model pembelajaran kooperatif tipe permainan kartu domino dalam pembelajaran. Adapun aktivitas guru yang kurang nampak atau penyebab sehingga belum tercapainya indikator kinerja yaitu selama pembelajaran berlangsung guru belum bisa mengorganisasikan waktu dengan baik, guru belum meberikan motivasi kepada siswa untuk belajar, guru belum memberikan gambaran yang lebih jelas kepada siswa mengenai tujuan sesungguhnya dari kegiatan belajar permainan kartu domino, guru belum menginformasikan pentingnya bekerja sama dalam kelompok untuk mendapat hasil belajar yang baik secara individual,

\section{Tindakan Sikulus II}

Berdasarkan pengamatan pada lembar observasi keefektifan mengajar guru, diperoleh informasi bahwa kinerja guru dalam menerapkan model pembelajaran kooperatif tipe permainan kartu domino pada mata pelajaran sejarah mengalami peningkatan yang signifikan. Dari 11 aspek yang diamati sudah mencapai $90,91 \%$ yang yang dilakukan oleh guru. Hal ini menujukan bahwa keefektifan mengajar guru mengalami peningkatan yang sangat signitifkan dimana hasil observasi keefektifan mengajar guru pada siklus I hanya mencapai persentase $72,73 \%$, sedangkan pada silus II keefektifran mengajar guru mencapai persentase 90,91\% dan hasil ini telah memenuhi indikator kinerja yangh telah ditentukan yaitu $90 \%$.

Analisis aktivitas siswa selama proses pembelajaran pada siklus II terlihat bahwa aktivitas siswa dalam proses pembelajaran sudahh memperlihatkan peningkatan yang signitif, dimanan dari 10 aspek yang diobservasi sudah mencapai $90 \%$ yang nampak pada kegiatan siswa selama proses pembelajaran berlangsung, yang artinya bahwa aktivitas siswa sudah mengalami peningkatan yang signifikan dari siklus I dimana persentase hanya menncapai 25\% sehingga peresentase aktivitas siswa pada siklus I belum mencapai indikator kinerja yang telah ditentukam yaitu $90 \%$ sedangkan pada siklus II aktivitas siswa sudah mencapai persentase $90 \%$, hal ini menujukan bahwa proses pembelajaran sejarah berjalan dengan baik pada siklus II dan kelemahan-kelemahan yang terjadi pada siklus I sudah dapat diatasi pada siklus II.

Berdasarkan hasil evaluasi pembelajaran siklus II yang dilaksanan pada tanggal 08 Februari 2018 diperoleh nilai hasil belajar dengan nilai minimum 65, nilai maksimum 95, dan dengan rata-rata 82 . Adapun distribusi skor perolehan hasil belajar siswa disajikan pada tabel berikut: 
Tabel 3: Distribusi Frekuensi Skor Hasil Belajar Siswa Pada Siklus II

\begin{tabular}{cccc}
\hline No & Hasil Belajar & Jumlah & Persentase (\%) \\
\hline 1. & $0-55$ & 0 & 0 \\
2. & $56-65$ & 2 & 8,70 \\
3. & $66-75$ & 1 & 4,35 \\
4. & $76-85$ & 13 & 56,52 \\
$\mathbf{5 .}$ & $86-95$ & 7 & 30,43 \\
& Jumlah & 23 & 100 \\
\hline
\end{tabular}

Sumber data: diolah dari data penelitian

Dari tabel 3 di gambarkan bahwa sudah tidak ada siswa yang memper oleh nilai 0-55, 2 orang siswa yang memperoleh nilai 56-65 denagn persentase $8,70 \%, 1$ orang siswa yang memperoleh nilai 66-75 dengan persentase 4,35\%, 13 orang yang memperoleh nilai 76-85 dengan persentase $56,52 \%$ dan 7 orang yang memperoleh nilai $86-95$ dengan persentase $30,43 \%$

Selanjutnya untuk melihat distribusi dan persentase ketuntasan hasil belajar siswa disajikan pada tabel berikut:

Tabel 4:Analisis Ketuntasan Hasil Belajar Siswa Pada Pembelajaran Siklus II

\begin{tabular}{ccc}
\hline Ketuntasan & Jumlah Siswa & Persentase (\%) \\
\hline Tuntas & 20 & 86,96 \\
Tidak tuntas & 3 & 13,04 \\
Jumlah & $\mathbf{2 3}$ & $\mathbf{1 0 0}$ \\
\hline
\end{tabular}

Sumber data: diolah dari data penelitian siklus II

Dari tabel 4 diatas, terlihat bahwa jika dianalisis secara persentase maka kentuntasan hasil belajar siswa mencapai 86,96\%. Dengan demikian maka indikator kinerja siswa secara klasikal yakni $80 \%$ telah mencapai target yang ditetapkan pada Siklus II

Berdasarkan hasil observasi keefektifan mengajar guru dan aktivitas siswa pada siklus IIsudah menunjukan peningkatan yang signifikan jika dibandingkan pada silkus I. Kegiatan pembelajaran pada siklus II sudah menunjukan hasil yang diharapkan, baik terhadap keefektifan mengajar guru maupun aktivitas belajar siswa. Dalam observasi keefektifan mengajar guru telah mencapai $90,91 \%$ dan aktivitas siswa mencapai $90 \%$ dalam proses pembelajaran dengan menerapkan model pembelajaran kooperatif tipe permainan kartu domino sudah menujukan hasil yang mencapai indikator kinerja yang telah ditentukan yaitu $90 \%$

Berdasarkan analisis hasil ketuntasan belajar diperoleh $86,96 \%$ siswa yang telah mencapai KKM. Hal ini munjukan bahwa dari 23 siswa sudah 20 siswa yang telah memahami materi pelajaran sejarah dengan menerapkan model pembelajaran kooperatif tipe permainan kartu domino.Hasil ini telah melampaui batas minimal indikator keberhasilan yang ditetapkan yakni $80 \%$. Dengan demikian hipotesis tindakan telah tercapai dengan menerapkan model pembelajaran kooperatif tipe permainan kartu domino dalam pembelajaran pada kopetensi dasar "Menganalisis hubungan antara perkembangan paham-paham baru dan dan transformasi sosial dengan kesadaran dan pergerakan kebangsaan ." pada siswa kelas XI IPS4 SMA Negeri I Kabawo dapat meningkatkan hasil belajar siswa. Secara umum gambaran perkembangan hasil belajar siswa untuk setiap siklus disajikan berikut ini:

Tabel 5: Analisis Ketuntasan Hasil Belajar Siswa Pada Setiap Siklus

\begin{tabular}{ccccc}
\hline Ketuntasan & \multicolumn{3}{c}{ Siklus I } & \multicolumn{2}{c}{ Siklus II } \\
\cline { 2 - 5 } Tuntas & $\mathrm{F}$ & $\%$ & $\mathrm{~F}$ & $\%$ \\
Tidak tuntas & 15 & 65,22 & 20 & 86,96 \\
Jumlah & 8 & 34,78 & 3 & 13,04 \\
\hline
\end{tabular}

Sumber data: diolah dari hasil penelitian 


\section{Pembahasan}

Penelitian ini adalah penelitian tindakan kelas (PTK), dimana penelitian tindakan kelas ini dengan penerapan model pembelajaran kooperatif tipe permainan kartu domino dalam pembelajaran merupakan salah satu upaya dalam meningkatan hasil belajar pada mata pelajaran sejarah kelas XI IPS4 SMA Negeri I Kabawo.

Penelitian ini dilakukan selama dua siklus, dimana setiap siklus terdiri dari tiga kali pertemuan. Kegiatan pembelajaran akan dilaksanakan sesuai dengan model pembelajaran kooperatif tipe permainan kartu domino. Penelitian hasil belajar siswa ditentukan dengan indikator kinerja minimal $80 \%$ siswa telah mencapai Kriteria Ketuntasan Minimal (KKM) yang ditetapkan di SMA Negeri I Kabawo yaitu 76, dan skor perolehan nilai diambil dari hasil tes/evaluasi. Sedangkan penelian keefektifan guru dan aktivitas siswa ditentukan dengan indikator kinerja yaitu minimal 90\% skenario pembelajaran yang dilaksanakan dengan baik dan nilai tersebut diambil dengan menggunakan lembar observasi.

Proses peembelajaran mengacu pada pembelajaran dengan menerapkan model pembelajaran kooperatif tipe permainan kartu domino. Pembelajaran dimulai dengan guru menyiapkan tujuan pembelajran, kemudian setelah guru menyiapkan tujuan pembelajaran guru mengadakan apresiasi yang bertujuan untuk menggali pengetahuan dasar siswa mengenai materi yang akan diajarkan. Hal ini agar siswa dapat memahami arah dan tujuan pembelajaran yang akan dicapai. Setelah itu guru menyampaikan langkah-langkah model pembelajaran kartu domino, kemudian guru menguraikan/menjelaskan materi yang akan dipelajari, selanjutnya guru membagi siswa dalam kelompok dimana pada setiap siklus dibagi dalam 5 kelompok.

Berdasarkan dari hasil peneliatan yang didapatkan dari lembar observasi tentang keefektifan mengajar guru menujukan adanya perubahan kearah yang positif dari siklus I kesiklus II. Hal ini dapat dilihat dari keefektifa guru pada siklus I dengan persentase 72,73\% dari 11 aspek yang diobservasi 8 diantaranya yang terlaksana dan mengalami peningkatan yang signifikan pada siklus II dengan persentase mencapai 90,91\%dari 11 aspek yang diobservasi110 yang telah terlaksna. Peningkatan ini sesuai dengan apa yang telah dituangkan peneliti didalam indikator kinerja dimana dalam indikator kinerja dikatakan bahwa apoabila keefektifan mengajar guru mencapai angkah $90 \%$ maka pembelajaran yang dilakukan oleh guru tersebut telah dinyatakan berhasil atau telah sesuai dengan skenario pembelajaran. Adanya peningkatan keefektifan mengajar guru dari siklus I ke siklus II terjadi karena selama proses pembelajaran dengan menerapkan model pembelajaran kooperatif tipe permainankartu domino yang dilakukan guru khususnya dalam melaksanakan langkah-langkah pembelajaran semakin baik diamana hal-hal yang belum sempat terlaksana dan menjadi kendala pada siklus I tidak terjadi lagi pada siklus II. Adapun banyak kelamahan/penyebab sehingga belum dapat tercapai indikator kinerja yaitu, pada kegiatan pendahuluan guru belum memaksimalkan mengajukan pertanyaan untuk menggali informasi awal dari siswa terkait dengan yang akan diajarakan, dalam hal ini guru telah mengajukan apresiasi/pertanyaan awal hanya saja kurang memberi kesempatan kepada siswa berpikir sejenak untuk menjawab atau atau menanggapi apresiasi/pertanyaan. Selanjtunya guru belum memberikan motivasi kepada siswa sehinnga siswa masih kurang tertarik untuk mengikuti pelajaran.

Pada kegiatan akhir, guru tidak terlihat memimbing siswa dalam menyimpulkan materi pelajaran berhubung jam pelajaran telah selesai.Hal ini yang menyababkan tidak tercapainya prensentase kefektifan mengajar guru.Selain itu terjadinya peningkatan antara guru dan siswa yang membuat suasna pembelajaran dalam kelas menjadi nyaman bagi para siswa sehingga para siswa dapat merasakan suasana pembelajaran yang berbeda dari sebelumnya dimana mereka juga dapat mengungkapkan pendapat mereka tanpa rasa takut pada guru ataupun perasaan malu pada temanteman kelas. Dengn suasana belajar seperti ini tentunya turut memotivasi guru untuk melakukan sesuatu yang lebih baik lagi selama proses pembelajaran berlangsung khususnya dalam menerapkan model pembelajaran kooperatif tipe permainan kartu domino. Usaha yang dilakuakn guru untuk meniungkatkan aktuivitas mengajar guru didasarkan pada pendapat Dimyati dan Mudiojno(2013: 20) yang berisikan tentang prinsip-prinsip atau upaya yang harus dilakukan oleh 
seoramg guru didalam proses pembelajaran diantaranya yaitu: 1) perhatian dan miotivasi, yang guru harus memberikan perhatian dan motivasi untuk anak didiknya, 2) keaktifan, guru harus lebih aktif mengajak peran aktif siswa selama proses pembelajaran, 3) keterlibatan langsung, guru harus senantiasa terlibat langsung dalam proses pembelajaran untuk membangun komunikasi yang baik diantara keduanya, 4) pergaulan, guru dituntut untuk mengubah siswa selama proses pembelajaran berlangsung dimana dari kondisi siswa dari yang tidak tau menjadi tau meskipun seorang guru harus sering menjelaskan berulang-ulang. Hal ini tentu saja karena tidak semua siawa mampu mencerna pembelajaran hanya dengan ssekali pertamuan, 5) tantangan, guru harus siap menghadapi setiap rintangan yang ada khususnya didalam melaksanakan tugas, 6) balikan dan penguatan, penguatan adalah suatu hal yamg harus dilakukan seorang guru kepada siswanya, hal ini bertujuan untuk membri dorongan dan semangat kepada siswanya, 7) perbedaan individu, guru juga harus dituntut untuk memahami karakter dari masing-masing anak didiknya karena hal ini dapat memperngaruhi proses pembelajaran namun hal ini juga dapat dijadikan acuan bagi guru dalam melaksanakan pembelajaran khususnya dalam hal menentukan strategi, pendekatan dan model pembelajaran yang cocok untuk diterapkan didalam proses pembelajaran hal ini juga besar pengaruhnya terhadap peningkatan aktivitas mengajar guru.

Meningkatkan atau membaiknya keefektifan mengajar guru dari skilus I ke siklus II diikuti juga dengan aktivitas belajar siswa dimana aktivitas belajar siswa pada siklus I mencapai persentase $26 \%$ mengalami peningkatan pada siklus II dengan persentase $90 \%$.Pembelajaran tersebut juga telah mampu meningkatkan hasil belajar sejarah siswa di kelas XI IPS 4 SMA Negeri I Kabawo.Hal ini terlihat dari adanya peningkatan persentase jumlah siswa yang sudah tuntas dri siklus I sampai dengan siklus II. Pada siklus I terdapat 15 orang siswa atau $65,22 \%$ yang sudah tuntas dengan rataa-rata 73 dan 8 orang siswa atau 34,78\% yang belum tuntas dari 23 siswa kelas XI IPS4 SMA Negeri I Kabawo, sedangkan pada siklus II terdapat 20 orang siswa atau 86,96\% yang suda tuntas dengan rata-rata 82 dan 3 orang siswa atau 13,04\% yang belum tuntas dari 23 siswa.

\section{PENUTUP}

Berdasarkan paparan hasil penelitian dan pembahasan, dapat disimpulkan bahwa: pertama Penerapan model pembelajaran koopereatif tipe permainan kartu domino dalam pembelajaran sejarah di SMA Negeri I Kabawo dapat meningkatkankeefetifan mengajar guru dimana pada siklus I hanya mencapai persentase $72,73 \%$ pada siklus II mengalami peningkatan yang signifakan dengan capaian persentase 90,01\%; Kedua penerapan model pembelajaran koopereatif tipe permainan kartu domino dalam pembelajaran sejarah di SMA Negeri I Kabawo dapat meningkatkan aktivitas belajar siswa, dimana pada siklus I hanya mencapai perensentase $25 \%$ dan pada siklus II mengalami peningkatan yang signifikan dengan capaian persentase $90 \%$. Dan ketiga Dengan penerapan model pembelajaran kooperatif tipe permainan kartu domino dalam pembeljaran menujukan bahwa hasil belajar sejarah siswa meningkat, dimana hasil belajar yang diperoleh siswa pada siklus I yaitu dengan peroleh pesentase sebesar 55,22\% atau 15 0rang siswa dari 23 siswa dengan rat-rata 73 , dan pada siklus II meningkat, dengan perolehan persentase $86,96 \%$ atau 20 ornag siswa dari 23 siswa dengan rata-rata 82 .

\section{DAFTAR PUSTAKA}

Arikunto, Suharsimi .2002. Prosedur Penelitian Suatu Pendekatan Praktek, Jakarta : Rineka Cipta. Aunurahman, 2012. Belajar dan Pembelajaran. Bandung : Alfabeta

Erman, Suberman, dkk. 2003. Strategi Pembelajaran Matematika Kontemporer (Common Teks Books). Bandung: JICA Universitas Pendidikan Indonesia.

Ginnis Paul. 2008 Trik dan Taktik mengajar. Jakarta. Indeks

Hamulton et all. 2000. The Case For Leaning Outcomes

(http://efcefc/ca/trainingconection?learning.html) Diakses 29 -03-2017.

Ibrahim, Muslimin, dkk. 2000. Pembelajaran kooperatif. Surabaya: Universitas Pers 
E-ISSN: 2502-6674

$P-I S S N$ : 2502-6666

http://ojs.uho.ac.id/index.php/p_sejarah_uho

Moleong, Lexy. J. 2006. Metodologi Penelitian Kualitatif. Bandung : Remaja Rosdakarya Rostiah, N. K. 2001. Strategi Belajar Mengajar. Jakarta. Rineka Cipta.

Sardiman, A.M. 2016 Interaksi dan Motivasi Belajar Mengajar. Jakarta: Rajawali Perss 